\title{
ANALISIS FIKIH SISTEM PEMBIAYAAN MUDHARABAH DALAM PRAKTIK DAN PERATURAN PERUNDANG-UNDANGAN PERBANKAN SYARI'AH
}

\author{
Nining Sri Wahyuni \\ Lecturer of Teacher Training and Educations Sciences Faculty \\ at Graha Nusantara University Padangsidimpuan \\ Email: illiyinijabah@yahoo.co.id
}

\begin{abstract}
The aims of this research are to give the understanding about comparation of System Capital Mudharabah Costing in practice of Shariah Banking with Fiqh, to give understanding about the suitable of the Mudharabah practice in Shariah Banking with the rale of law Shariah Banking, and to give the understanding of the appropriate of Mudharabah practice in the rale of law Shariah Banking with Fiqh. To give the explanation above through a research with used normative and sociology method and instrument for collecting data are document data given from Mualamah Bangking in Medan. It is showed the practice of the Capital Mudharabah Collecting in Shariah Banking is still not suitable to Shariah principle in Fiqh.
\end{abstract}

Keyword: Capital, Mudharabah, Fiqh Analysis

\begin{abstract}
Abstrak
Tujuan dari penelitian ini adalah pertama untuk memberikan pengetahuan tentang perbandingan sistem pembiayaan modal mudharabah dalam praktek perbankan syariah dengan ilmu fikih. Kedua, untuk memberikan pengetahuan tentang cocok atau tidaknya praktek mudharabah di perbankan syariah dengan aturan hukum perbankan syariah. Ketiga, untuk memberikan pengetahuan tentang cocok atau tidaknya praktek mudharabah dalam aturan hukum perbankan syariah dengan ilmu fikih. Untuk mempelajari penjelasan di atas untuk melakukan penelitian dengan metode normatif dan sosiologi dan alat pengumpulan data sekunder adalah studi pustaka atau studi dokumen dan alat pengumpulan data primer telah diberikan kepada Bank Muamalat di Medan. Hasil penelitian ini menunjukkan bahwa praktik pengumpulan modal mudharabah di perbankan syariah masih belum sesuai dengan prinsip syariah dalam ilmu fikih.
\end{abstract}

Kata Kunci: Modal, Mudharabah, Analisis Fikih

\section{PENDAHULUAN}

Islam melarang riba:

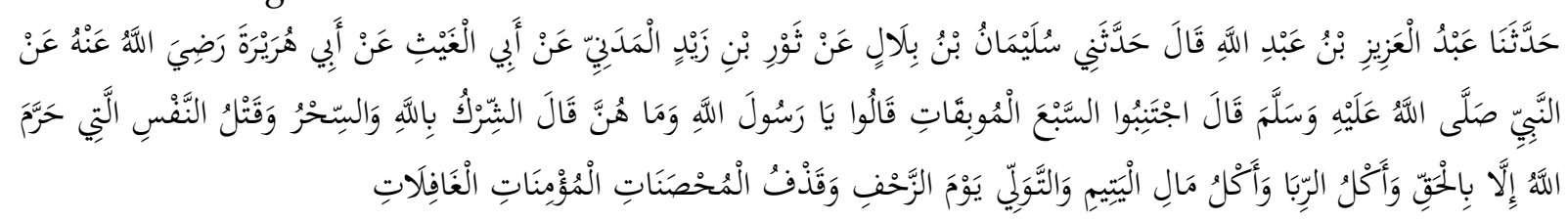

Atrinya: (BUKHARI - 2560) : Telah bercerita kepada kami 'Abdul 'Aziz bin 'Abdullah berkata telah bercerita kepadaku Sulaiman bin Bilal dari Tsaur bin Zaid Al Madaniy dari 
Abu 'Al Ghoits dari Abu Hurairah radliallahu 'anhu dari Nabi shallallahu 'alaihi wasallam bersabda: "Jauhilah tujuh perkara yang membinasakan". Para sahabat bertanya: "Wahai Rasulullah, apakah itu? Beliau bersabda: "Syirik kepada Allah, sihir, membunuh jiwa yang diharamkan oleh Allah kecuali dengan haq, memakan riba, makan harta anak yatim, kabur dari medan peperangan dan menuduh seorang wanita mu'min yang suci berbuat zina". ${ }^{1}$

Pada hadis lain disebutkan bahwa perbuatan riba itu derajatnya 36 kali lebih besar dosanya dibandingkan dengan dosa berzina, Rasulullah SAW bersabda:" Satu dirham yang diperoleh oleh seorang dari perbuatan riba lebih besar dosanya 36 kali daripada perbuatan zina di dalam islam (setelah masuk islam)" ${ }^{2}$ Oleh karena itu sebagai umat islam mau tidak mau memang dituntut untuk tetap istiqomah dalam menjalankan syariat Allah dengan sekuat tenaga, untuk tidak terlibat dalam praktik ribawi perbankan konvensional saat ini. Memang pasti terasa sulit apalagi jka memang kita sedang dalam kondisi kesullitan ekonomi dan perlu dana mendesak. Allah SWT berfirman dalam QS: Azzalzalah : 6- 7

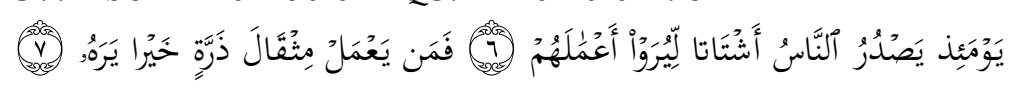

Artinya:"Barang siapa yang mengerjakan kebaikan seberat dzarrahpun, niscaya dia akan melihat balasannya. Dan barang siapa yang mengerjakan kejahatan seberat dzarrahpun, niscaya dia akan melihat balasannya pula".

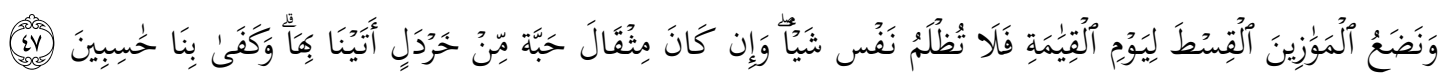

Artinya: Allah SWT berfirman:"Kami akan memasang timbangan yang tepat pada hari kiamat, maka tiadalah dirugikan seseorang barang sedikitpun, dan jika (amalan) itu hanya seberat biji sawipun pasti kami mendatangkan (pahala)nya. Dan cukuplah kami sebagai pembuat perhitungan (QS: Al-Anbiyaa':47)

Rasulullah SAW :"Azab yang paling ringan di neraka pada hari kiamat adalah seseorang yang pada dua telapak kakinya ada dua bongkah bara api. Lalu bara api ini akan merebus otak orang tersebut". (HR: At-Tirmidzi). Situasi semacam ini membuat umat islam menghadapi dilema yang cukup pelik. Disatu sisi mereka menyadari akan perlunya lembaga perbankan untuk menyelesaikan masalah ekonomi masyarakat. Namun disisi lain mereka dihadapkan pada ajaran agama yang mengharuskan menghindari diri dari segala transaksi riba, oleh karena hal tersebutlah maka muncul ide untuk membentuk perbankan syariah. ${ }^{3}$

\section{PEMBAHASAN}

\section{Sejarah Dan Latar Belakang lahirnya Bank Syariah.}

${ }^{1}$ HR. Bukhari dan Muslim, Abu Dawud, An-Nasai dari Abu Hurairah.

${ }^{2} \mathrm{HR}$. Al-Baihaiqy dari Annas Bin Malik.

${ }^{3}$ Muhammad, 2008, Manajemen pembiayaan MudharabahBank Syariah, Jakarta: PT raja Grafindo Persada, halaman 17-18. 
Pendirian bank syariah dimaksudkan untuk menghapus riba pada bank konvensional, dan menggantinya dengan aktivitas perdagangan barang dan jasa sesuai QS: Al-Baqarah: 275.

Selain itu ide ini juga tidak terlepas dari kontroversi seputar praktik bunga bank yang dilakukan pada bank konvensional yang beredar di negeri-negeri islam. ${ }^{4}$

Di Indonesia ide membentuk bank syariah sudah mulai terlihat sejak awal tahun 1940-an, dan sudah mendapat kata ssepakat dari para ahli ekonom pada tahun 1960, namun pada dekade ini kondisinya tidak memungkinkan untuk merealisasikan pendirian bank-bank syariah, karena pembentukan bank islam mula-mula banyak menimbulkan keraguan. Hal tersebut muncul karena adanya anggapan bahwa sistem perbankan bebas bunga adalah sistem yang mustahil dan tidak lazim sehingga timbul pula pertanyaan tentang bagaimana nantinya bank islam tersebut membiayai operasionalnya. ${ }^{5}$ Sedangkan perbankan syariah di Negara Mesir di bentuk tanpa menggunakan embel-embel islam karena adanya kekhawatiran rezim yang berkuasa saat itu akan melihatnya sebagai gerakan fundamentalis. ${ }^{6}$ Hingga akhirnya pada tanggal 1 Mei 1992 bank Muamalat sebagai bank syariah pertama di Indonesiapun tegak dan menjadi cikal bakal perkembangan bank syariah di Indonesia hingga sekarang.

\section{Defnisi, Rukun, Jenis, Mudharabah}

\section{a. Definisi Mudharabah.}

Mudharabah juga disebut dengan qirad yaitu syarikah yang terbentuk antara dua pihak, pihak pertama menyediakan keseluruhan modal (shahibul maal) dan pihak lainnya menjadi pengelola. Pihak shahibul maal bersepakat untuk menyerahkan modalnya kepada pengelola untuk dikelola, keuntungan usaha dibagi sesuai dengan proporsi yang disepakati dan dituangkan dalam kontrak. Adapun apabila terjadi kerugian akan ditanggung oleh shahibul maal selama bukan akibat kelalaian pengelola (mudharib), dalam hal ini kategori mudharabah mencakup juga antara dua pemodal dengan pengelolanya salah satu dari dua pemodal tersebut. Begitu pula jika ada dua orang pemodal melakukan mudharabah dengan pengelola dari pihak lain di luar pemodal. Maka praktik inipun termasuk dalam kategori mudharabah.

Mudharabah dinyatakan sah jika modalnya diserahkan kepada pihak pengelola dengan masing-masing pihak saling memberikan kepercayaan. Modal yang diserahkan untuk dikelola harus jelas nilainya. Setelah modal diserahkan, pihak pemodal tidak diperbolehkan ikut melakukan pengelolaan seccara mutlak, sebab prinsip mudharabahadalah penyerahan modal secara penuh kepada pihak pengelola.

${ }^{4}$ M. Syafi'I Antonio dkk, 2006, Bank Syariah Analisis Kekuatan, Kelemahan, Peluang, Dan Ancaman, Yogyakarta: Ekonisia, halaman 139.

${ }^{6}$ Ibid, Halaman 1

${ }^{6}$ bid, Halaman 2 
Shalih bin Shuhaib ra, juga menuturkan bahwa Rasulullah SAW bersabda :"ada tiga hal yang di dalamnya terdapat keberkahan: jual beli secara tangguh, muqaradhah (mudharabah), dan mencampur gandum dengan tepung untuk keperluan rumah bukan untuk dijual". ${ }^{7}$

\section{b. Rukun Mudharabah.}

Menurut jumhur ulama, rukun mudharabah ada tiga yaitu: 1) Aqid, yaitu pemilik modal dan pengelola ('amil/mudharib), 2)Ma'qud 'alaih yaitu modal, tenaga(pekerjaan) dan keuntungan, 3)Shighat yaitu ijab dan qabul.

Sedangkan Syafi'iyah menyatakan bahwa rukun mudharabah ada 5: 1)Modal,

2)Tenaga/ pekerjaan, 3)Keuntungan, 4)Shighat(Ijab,Qabul), 5)'Aqidain ( Pemilik modal dan Pengelola) ${ }^{8}$.

\section{c. Jenis mudharabah.}

Mudharabah terbagi dua bagian :

\section{Mudharabah Muthlaqah.}

Merupakan akad yang pemilik modalnya memberikan modal kepada 'amil (pengelola) tanpa disertai dengan pembatasan (qaid), contohnya seperti kata pemilik modal :"Saya berikan modal ini kepada anda dengan mudharabah, dengan ketentuan bahwa keuntungan dibagi dua atau dibagi tiga", dalam akad tersebut tidak ada keuntungan atau pembatasan mengenai tempat kegiatan usaha, jenis usaha, barang yang dijadikan objek usaha, dan ketentuan-ketentuan lain.

\section{Mudharabah Muqayyadah.}

Merupakan akad yang pemilik modal memberikan ketentuan atau batasanbatasan yang berkaitan dengan tempat kegiatan usaha, jenis usaha, barang yang menjadi objek usaha, waktu, dan dari siapa barang tersebut dibeli. Pembatasan dengan waktu dan orang yang menjadi sumber pembelian barang dibolehkan menurut Abu Hanifah dan Ahmad, sedangkan menurut Malik dan Syafi'i tidak dibolehkan. Demikian pula menyandarkan akad kepada waktu yang akan datang dibolehkan menurut Imam Malik dan Syafi'i. ${ }^{9}$

\section{d. Sifat Mudharabah.}

Akad mudharabah tidak bisa dibatalkan sampai barang-barang dagangan berubah menjadi uang. Disamping itu akad tersebut juga bisa diwaris. Menurut Imam Abu Hanifah, Syafi'i, dan Ahmad, meskipun mudharib telah memulai kegiatan usahanya, akad tersebut tetap tidak mengikat (ghair lazim) sehingga setiap saat bisa dibatalkan, disamping itu akad tersebut tidak bisa diwaris. ${ }^{10}$

\footnotetext{
${ }^{7}$ HR. Ibnu Majah

${ }^{8}$ Ibid

${ }^{9}$ Ibid, Halaman 372

${ }^{10}$ Ibid
} 
Jumhur ulama menyamakan akad sesudah dimulai kegiatan usaha dengan sebelum dimulainya kegiatan. Hal tersebut dikarenakan mudharabah adalah suatu tasharuf terhadap harta milik orang lain dengan persetujuannya. Oleh karena itu masing-masing pihak memiliki hak untuk membatalkan akad seperti halnya dalam wadi'ah dan wakalah. ${ }^{11}$

\section{Sistem Pembiayaan Mudharabah Di Dalam Peraturan Perundang-Undangan.}

Legalitas syariah dari produk pembiayaan mudharabah ini didasarkan pada fatwa DSN-MUI No :07/DSN-MUI/IV/2000 Tentang Pembiayaan mudharabah (Qiradh) . Fatwa ini menjelaskan tentang ketentuan umum pembiayaan mudharabah sebagai berikut :

a. Pembiayaan mudharabah adalah pembiayaan yang disalurkan oleh LKS (Lembaga Keuangan Syariah) kepada pihak lain untuk suatu usaha yang produktif.

b. Dalam pembiayaan ini LKS sebagai shahibul maal (pemilik dana) membiayai $100 \%$ kebutuhan suatu proyek (usaha), sedangkan pengusaha (nasabah) bertindak sebagai mudharib (pengelola usaha).

c. Jangka waktu usaha, tata cara pengembalian dana, dan pembagian keuntungan ditentukan berdasarkan kesepakatan kedua belah pihak (LKS dengan pengusaha).

d. Mudharib boleh melakukan berbagai macam usaha yang telah disepakati bersama dan sesuai dengan syariah, dan LKS tidak ikut serta dalam menejemen perusahaan /proyek tetapi mempunyai hak untuk melakukan pembinaan dan pengawasan.

e. Jumlah dana pembiayaan harus dinyatakan dengan jelas dalam bentuk tunai dan bukan piutang.

f. LKS sebagai penyediaan dana menanggung semua kerugian akibat dari mudharabah kecuali jika mudharib (nasabah) melakukan kesalahan yang disengaja, lalai, atau menyalahi perjanjian.

g. Pada prinsipnya dalam pembiayaan mudharabah tidak ada jaminan, namun agar mudharib tidak melakukan penyimpangan, LKS dapat meminta "jaminan" dari mudharib dari pihak III. Jaminan ini hanya dapat dicairkan apabila mudharib terbukti melakukan pelanggaran terhadap hal-hal yang telah disepakati bersama dalam akad.

h. Kriteria pengusaha, prosedur pembiayaan, dan mekanisme pembagian keuntungan diatur oleh LKS dengan memperhatikan fatwa DSN.

i. Biaya operasional dibebankan kepada mudharib.

j. LKS tidak melakukan kewajiban atau melakukan pelanggaran terhadap kesepakatan, mudharib berhak mendapati ganti rugi atau biaya yang telah dikeluarkan.

Selain menjelaskan ketentuan umum pembiayaan mudharabah, fatwa tersebut juga menjelaskan tentang rukun dan syarat pembiayaan yaitu sebagai berikut:

\footnotetext{
${ }^{11}$ Ibid, halaman 373
} 
a. Penyediaan dana (shahibul maal) dan pengelola (mudharib) harus cakap hukum.

b. Pernyataan ijab dan qabul harus dinyatakan oleh para pihak untuk menunjukan kehendak mereka dalam mengadakan kontrak (akad), dengan memperhatikan halhal berikut:

1) Penawaran dan penerimaan harus secara eksplisit menunjukan tujuan kontrak (akad).

2) Penerimaan dari penawaran dilakukan paada saat kontrak.

3) Akad dituangkan secara tertulis melalui korespondensi atau dengan menggunakan cara-cara komunikasi modern.

c. Modal ialah sejumlah uang dan/atau asset yang diberikan oleh penyedia dana kepada mudharib untuk tujuan usaha dengan syarat sebagai berikut:

1) Modal harus diketahui jumlah dan jenisnya.

2) Modal dapat berbentuk uang atau barang yang dinilai. Jika modal diberikan dalam bentuk asset, maka asset tersebut harus dinilai pada waktu akad.

3) Modal tidak dapat berbentuk piutang dan harus dibayar kepada mudharib, baik secara bertahap maupun tidak, sesuai dengan kesepakatan dalam akad.

d. Keuntungan mudharabah adalah jumlah yang di dapat sebagai kelebihan dari modal. Syarat keuntungan berikut ini harus dipenuhi:

1) Harus diperuntukan bagi kedua pihak dan tidak boleh disyaratkan hanya untuk satu pihak.

2) Bagian keuntungan proporsional bagi setiap pihak harus diketahui dan dinyatakan pada waktu kontrak disepakati dan harus dalam bentuk persentasi (nisbah) dari keuntungan sesuai dengan kesepakatan. Perubahan nisbah harus berdasarkan kesepakatan.

3) Penyediaan dana menanggung semua kerugian akibat dari mudharabah, dan pengelola tidak boleh menanggung kerugian apapun kecuali diakibatkan dari kesalahan disengaja, kelalaian, atau pelanggaran kesepakatan.

e. Kegiatan usaha oleh pengelola (mudharib), sebagai perimbangan (muqabil) modal yang disediakan oleh penyedia dana, harus memperhatikan hal-hal berikut:

1) Kegiatan usaha adalah hak eksklusif mudharib, tanpa campur tangan penyedia dana, tetapi ia mempunyai hak untuk melakukan pengawasan.

2) Penyedia dana tidak boleh mempersempit tindakan pengelola sedemikian rupa yang dapat menghalangi tercapainya tujuan mudharabah, yaitu keuntungan.

3) Pengelola tidak boleh menyalahi hukum syariah islam dalam tindakannya yang berhubungan dengan mudharabah, dan harus mematuhi kebiasaan yang berlaku dalam aktifitas itu. 
Fatwa yang sama juga menjelaskan beberapa ketentuan hukum yang terkait dengan pembiayaan mudharabah (qiradh) ini :

1) Mudharabah boleh dibatasi pada periode tertentu.

2) Kontrak tidak boleh dikaitkan (mu'allaq) dengan semua kejadian di masa depan yang belum tentu terjadi.

3) Pada dasarnya dalam mudharabah tidak ada ganti rugi karena pada dasarnya akad ini bersifat amanah (yad al-amanah), kecuali akibat kesalahan disengaja, kelalaian, atau pelanggaran kesepakatan.

4) Jika salah satu pihak tidak menunaikan kewajibannya atau jika terjadi perselisihan di antara kedua belah pihak, maka penyelesaiannya dilakukan melalui Badan Arbitrasi Syariah setelah tidak tercapai kesepakatan melalui musyawarah.

Dasar yang digunakan dalam fatwa ini antara lain nash-nash Al-Qur'an, Assunah, Ijma', Qiyas, dan pendapat ulama. Fatwa ini menggunakan Al-Qur'an surah An-Nisa' : 29, Al-Baqarah : 283, Al-Maidah : 1, dan 2.

Adapun hadis yang digunakan sebagai dasar adalah hadis yang menjadi dalil mudharabah (HR: At-Thabrani dari Ibnu Abbas), hadis Shihaib dari Ibnu Majah, hadis At-Tirmidzi dari Amr Bin Auf tentang perdamaian. Mengenai ijma' fatwa ini mengutip ijma' sahabat yang sama (Wahbah Zuhaily, Al-fiqh Al-islami Wa Adilatuhu, 1989,IV/838).Sedangkan qiyas akad mudharabah ini yakni penyerahan sejumlah harta (dana/modal) dari satu pihak (shahibul maal) kepada pihak lain ('amil/mudharib) untuk diperniagakan (diproduktifkan) dan keuntungan dibagi diantara mereka sesuai kesepakatan, dapat diqiyaskan pada akad musaqat dalam kasus pertanian. Selain itu fatwa ini juga mengutip kaidah fikih yang menyatakan :Pada dasarnya semua bentuk muamalah boleh dilakukan kecuali ada dalil yang mengharamkannya". Juga pandangan para ulama yang menyatakan dalam kenyataan banyak orang yang mempunyai harta namun tidak mempunyai kepandaian dalam usaha memproduktifkannya, sementara itu tidak sedikit pula orang yang tidak memiliki harta namun ia mempunyai kemampuan dalam memproduktifkannya, karena itu diperlukan adanya kerja sama diantara kedua phak tersebut.

\section{Analisis Fikih Pembiayaan Mudharabah Dalam Peraturan Perundang-Undangan.}

\section{a. Analisis Fikih Terhadap Aspek Dalil Pembiayaan Mudharabah.}

Aspek dalil yaitu dalalah, wajh al-istidlal dari kaifiyatu al-istidlal sebagaimana yang telah dijelaskan di atas, nash-nash al-Qur'an yang digunakan di atas sebenarnya tidak secara langsung terkait dengan praktik mudharabah. 
Adapun dalil yang secara langsung terkait dengan mudharabah (dalam bahasa Iraq) dan Qiradh (dalam bahasa Hijaz), adalah hadis dari At-Thabrani dari Ibnu Abbas, Ijma' sahabat, dan Qiyas. Meskipun dalam konteks Qiyas ini juga masih diperselisihkan oleh para ulama yang menolak mengggunakan Musaqat sebagai hukum asal mudharabah.

\section{b. Analisis Fikih Terhadap Aspek Hukum Pembiayaan Mudharabah.}

1. Status LKS (Lembaga Keuangan Syariah) atau bank sebagai shahibul maal.

Dilihat dari proses penggalangan dana yang disalurkan dalam fitur pembiayaan mudharabah ini hanya ada dua kemungkinan yaitu wadi'ah dan mudharabah. Pada sistem wadi'ah dana yang disalurkan oleh bank kepada nasabah dalam fitur pembiayaan mudharabah adalah milik nasabah lain, bukan milik bank. Posisi bank disini sebenarnya menjadi wakil dari pemilik dana. Meski boleh saja dana yang dititipkan nasabah kepada bank dengan akad wadi'ah ini digunakan sesuai dengan izin pemiliknya, tetapi status bank tetap bukan menjadi shahibul maal., melainkan hanya wakil shahibul maal. Begitu juga jika dana yang disalurkan bank dalam pembiayaan mudharabah tersebut dikumpulkan melalui akad mudharabah, maka dana tersebut juga bukan milik bank, tetapi milik nasabah lain. Posisi bank disini juga bukan sebagai shahibul maal ,tetapi mudharib dari shahibul maal yang sesungguhnya yaitu nasabah. Pada titik ini status akad mudharabah ini jelas tidak sah, karena mudharib mengelola harta yang tidak boleh dikelola.

Keuntungan yang didapatkan oleh bank dari hasil pembiayaan dengan akad mudharabah ini sebenarnya bukan hak bank, karena dana tersebut merupakan dana pihak lain yaitu nasabah yang menjadi shahibul maal yang sesungguhnya. Jika alasan yang digunakan untuk membolehkan bank mendapatkan keuntungan tersebut adalah wakalah bi al-ujrah, maka alasan tersebut tidak tepat. Pertama, status bank ketika akad dengan pihak pemilik dana (shahibul maal) yang sesungguhnya adalah akad mudharabah, dimana bank sebagai pengelolanya. Namun nyatanya bank tidak mengelola sendiri, tetapi diserahkan kepada pihak lain yang menjadi mudharib bank, dimana bank menjadi shahibul maalnya. Pada akad kedua yang tidak bisa dilepaskan dari akad pertama ini, bank telah mewakilkan dirinya sebagai pengelola (mudharib), dalam hal ini kebolehan praktik tersebut dianalogikan dengan akad wakalah, padahal faktanya jelas berbeda. Analogi seperti ini telah ditolak oleh Ibn Qudamah. ${ }^{12}$ Kedua, jika bank berhak mendapatkan kompensasi karena wakalah bi al-ujrah, maka apa yang diklaim sebagai ujrah tersebut sesungguhnya bukan hak bank, karena ia tidak melakukan aktivitas apapun baik sebagai ajir maupun mudharib (pengelola).

\footnotetext{
${ }^{12}$ Ibn Qudamah, 2004, Op.Cit, Halaman 1082
} 
2. Adapun status jaminan dalam akad mudharabah memang merupakan pandangan syar'i, setidaknya menurut mazhab Hanafi. Sekalipun argumentasi yang digunakan adalah istihsan, agar mudharib tidak lalai dan melanggar ketentuan yang telah disepakati ${ }^{13}$. Namun dalil istihsan ini bertentangan dengan hadis Nabi yang menyatakan:"Tidak ada kewajiban untuk menjamin bagi orang yang mendapatkan amanah". (HR: Al-Baihaqi dan Ad-Daruquthni dari Amr Bin Syu'aib Dari bapaknya, dari kakeknya).

Mudharib pada dasarnya adalah orang yang mendapatkan amanah dari shahibul maal. Apapun yang dia lakukan adalah sama dengan yang dilakukan oleh shahibul maal, karena itu jika terjadi resiko akibat dari tindakan mudharib, pada dasarnya sama dengan apa yang dilakukan oleh shahibul maal sendiri.

\section{PENUTUP}

Berdasarkan pembahasan di atas dapat disimpulkan bahwa:Bank syariah ada meminta jaminan kepada nasabah pembiayaan mudharabah, padahal hal tersebut jelas tidak boleh. Kedudukan bank sebagai pemilik modal pada akad pembiayaan mudharabah, adalah tidak tepat, ebab pemilik modal yang sesungguhnya bukan bank tetapi nasabah tabungan dan deposito mudharabah. Dalil yang digunakan dalam fatwa DSN-MUI No :07/DSNMUI/IV/2000 Tentang Pembiayaan mudharabah (Qiradh) tersebut adalah tidak tepat.

${ }^{13}$ As-Samargandi, 1993, Al-Mabsuth,Bent, Dan Al-Kutub Al-'ilmiyyah, Juz III, Halaman 19. 


\section{DAFTAR PUSTAKA}

Abdullah Saeed, 2004, Bank Islam Dan Bunga Studi Kritis Dan Interpretasi Kontemporer Tentang Riba Dan Bunga, Pustaka Pelajar Yogyakarta.

Abu Fuad, 2007, Riba Halal, Riba Haram, Pustaka Thariqul izzah, Bogor.

Adiwarman. A.Karim, 2010, Bank Islam Analisis Fikih Dan Keuangan, PT. Raja Grafindo Persada, Jakarta.

Adrian Sutedi,2009, Perbankan Syariah Dari Beberapa Segi Hukum, Ghalia Indonesia, Bogor.

Ahmad Wardi Muslich, 2010, Fikih Muamalat, Amzah: Jakarta.

As-Sya'rawi Fadhl, 2007, Al-Mash Arif Al-Islamiyah Firasah Ilmiyah Fiqliyal Mumarasat AlAmaliyah (Beirut : Ad dar Az Jami'iyah) Bambang Sunggono, 1997, Metode Penelitian Hukum,PT. Raja Grafindo Persada, Jakarta.

Fauzan Al-Banjari, 2008, Hukum islam seputar Riba Dan Pegawai Bank, Ar-Raudhoh Pustaka, Yogyakarta.

Hafidz Abdurrahman, 2003, Ushul Fikih Membangun Paradigma Berfikir Tasyri'i, Al-Azhar Press: Bogor.

Iyad Hilal,2005, Studi Tentang ushul Figh, Pustaka Thoriqul Izzah: bogor.

Iman Jauhari, 2010, Hukum Perbankan Islam, Buku Ajar Fakultas Hukum Universitas Syiah Kuala Darus Salam Banda Aceh.

Ibn Qudamah, 2004, Al-Mughni, Bait Al-Afkar Ad Dawaliyyah, Lebanon.

Jaih Mubarok, 2004, Perkembangan Fatwa Ekonomi Syariah Di Indonesia, Pustaka Bani Quraisy, Bandung.

Komunitas Pengusaha Rindu Syariah, 2010, pokok-pokok Panduan Implementasi Syariah Dalam Bisnis, Pustaka Rindu Syariah: Bogor.

M. Nezatullah Siddiqi, 1996, Kemitraan Usaha Dan Bagi Hasil Dalam Hukum Islam, Dana bakti prima: Yogyakarta.

M. Syafi'I Antonio dkk, 2006, Bank Syariah Analisis Kekuatan, Kelemahan, Peluang, Dan Ancaman, Yogyakarta.

Muhammad Yusuf, Wiroso, 2007, Bisnis Syariah, Mitra Wacana Media, Jakarta.

Muhammad, 2008, Manajemen Pembiayaan MUDHARABAH Di Bank Syariah, PT. Raja Grafindo Persada: Jakarta. 
Rachmat Syafei, 2001, Figh Muamala Untuk UIN, STSIN,PTAIS, Dan Umum, Pustaka Setia , Bandung.

Ridwan Nurdin, 2010, Figh Muamalah (Sejarah, Hukum, Dan Perkembangannya), Yayasan Pena: banda Aceh.

Sayyid Sabiq, 1995, Fikih Sunnah, Pustaka Percatakan offset, Bandung.

Satjipto Rahardjo, 1991, Ilmu Hukum, PT. Citra Aditya Bakti, Bandung.

Sunarto Zulkifli, Panduan praktis Transaksi Perbankan Syariah, zikrul hakim: Jakarta.

Taqiyuddin An-Nabhani, 1990, An-nidzam Al-Iqtishodi, Darul Ummah, Beirut.

Wiroso, 2005, Penghimpunan dana Dan Distribusi Hasil Usaha bank Syariah, Grasindo.

Yahya Abdurrahman, 2008, Hukum Seputar Transaksi Leasing, Al-Azhar Press, Bogor.

Yahya Abdurrahman, 2010, Tinjauan Kritis Seputar Koperasi, Al-Azhar Press, Bogor.

Zainuddin Ali, 2008, Hukum Perbankan Syariah, Sinar Grafika, Jakarta. 
FITRAH Vol.02 No. 1 Januari-Juni 2016

Kompetensi Guru dalam Melaksanakan dan Mengelola Proses Belajar Mengajar di Pondok Pesantren Darul Mursyidi Desa Sialogo Tapanuli Selatan 